\title{
Siphonaptera of small rodents and marsupials in the Pedra Branca State Park, State of Rio de Janeiro, Brazil
}

\author{
Sifonápteros de pequenos roedores e marsupiais do Parque Estadual da Pedra Branca, \\ Estado do Rio de Janeiro, Brasil \\ Heloiza H. Oliveira ${ }^{1}$; Adilson B. Almeida ${ }^{2}$; Raimundo W. Carvalho²*; Valmir Gomes ${ }^{3}$; \\ Nicolau M. Serra-Freire ${ }^{3}$; Igor Quinelato ${ }^{4}$; Acácio G. Carvalho ${ }^{1}$
}

${ }^{1}$ Post-Graduate Program in Environmental and Forestry Sciences, Instituto de Florestas, Universidade Federal Rural do Rio de Janeiro - UFRRJ

${ }^{2}$ Sérgio Arouca School of Public Health, Fundaçấo Oswaldo Cruz - FIOCRUZ

${ }^{3}$ Laboratory of Entomological Biodiversity, National Reference in Vectors of Rickettsiae, Instituto Oswaldo Cruz, Fundação Oswaldo Cruz - FIOCRUZ

${ }^{4}$ Department of Forestry Products, Instituto de Florestas, Universidade Federal Rural do Rio de Janeiro - UFRRJ

Received June 8, 2009

Accepted August 6, 2009

\begin{abstract}
In an region of Atlantic Rainforest corresponding to the geopolitical area of the Pedra Branca State Park, Rio de Janeiro, southeastern Brazil, 160 small mammals were captured, of which 64 rodents and 96 marsupials from October 2005 to October 2007. There were collected in these hosts six flea species from three families (Ctenophthalmidae, Rhopalopsyllidae and Pulicidae), totalizing 162 specimens. Adoratopsylla (Tritopsylla) intermedia intermedia was the most common species found, followed by Polygenis (Polygenis) occidentalis occidentalis. Philander frenatus and Micoureus paraguayanus were reported as new hosts to Adoratopsylla (Tritopsylla) intermedia intermedia and P. o. occidentalis was reported for the first time in the city of Rio de Janeiro.
\end{abstract}

Keywords: Siphonaptera, Rodentia, Didelphimorphia, ectoparasites, fleas.

\section{Resumo}

Na Mata Atlântica área correspondente ao espaço geopolítico do Parque Estadual da Pedra Branca, Rio de Janeiro, Brasil, entre outubro de 2005 e outubro de 2007, 160 pequenos mamíferos foram capturados, sendo 64 pequenos roedores e 96 marsupiais. Nestes hospedeiros, foram coletadas seis espécies de pulgas relacionadas a três famílias (Ctenophthalmidae, Rhopalopsyllidae e Pulicidae), totalizando 162 espécimes. Adoratopsylla (Tritopsylla) intermedia intermedia foi a espécie mais freqüente, seguida por Polygenis (Polygenis) occidentalis occidentalis. Novos hospedeiros foram registrados, Philander frenatus e Micoureus paraguayanus para Adoratopsylla (Tritopsylla) intermedia intermedia, bem como a ocorrência de algumas espécies de Siphonaptera encontrados em novo espaço geopolítico, P. o. occidentalis e no município do Rio de Janeiro.

Palavras-chave: Siphonaptera, Rodentia, Didelphimorphia, ectoparasitos, pulgas.

\section{Introduction}

The Pedra Branca State Park (PBSP) was legally established in 1974 and is an important reference for the preservation of the remaining rainforest in the city of Rio de Janeiro. It is characterized by natural forest regrowth that occurred after intense exploration with coffee and citrus cultivation between the mid-nineteenth

\footnotetext{
*Corresponding author: Raimundo Wilson de Carvalho

Escola Nacional de Saúde Pública Sérgio Arouca,

Fundação Oswaldo Cruz - FIOCRUZ,

Av. Leopoldo Bulhóes, 1480, Manguinhos, CEP 21041-210

Rio de Janeiro - RJ, Brazil

e-mail: raicar@ioc.fiocruz.br
}

century and the beginning of the twentieth century. Nowadays, this park has an area of 12.5 thousand ha, reaching $1,024 \mathrm{~m}$ above sea level, and is one of the most important urban forest in the world, showing exuberant fragments of the Atlantic Rainforest (DEAN, 1995).

The Brazilian Atlantic forest is considered one of the ecosystems with the highest biodiversity and levels of endemism in the planet (FONSECA, 1985; BROOKS; BALMFORD, 1996; MYER et al., 2000). There is a remarkable variation in local diversity of areas along its extension. Although not many in-depth and specific studies have been conducted, the information available for some 
groups of vertebrates and invertebrates is consistent with the idea that, in Southeast Brazil, more precisely, in the latitudes of the State of Rio de Janeiro, there is a high level of diversity of species for several groups. This high biodiversity can largely be explained by the characteristics of its rough relief and edaphic particularities of the region, which enable the occurrence of habitats (ROCHA et al., 2004).

Rodents and marsupials are recognized as reservoirs of several pathogens of viral infections, helminthiasis, bacteriosis and protozoosis (AZAD et al., 1992; MILLS et al., 1995; D'ANDREA et al., 2002; HORTA et al., 2007). Given their great adaptation capacity, some of them are assiduous species in rural and urban environments and many times are associated to the transfer of pathogenic agents to domestic animals and human populations. The ectoparasites of these small mammals such as ticks, fleas and lice can play a major role as vectors of these agents (SIMON, 1954; BRASIL et al., 1989; WEBB et al., 1990; WHO, 1999; CARVALHO et al., 2001a; OLIVEIRA et al., 2008).

The order Siphonaptera consists of approximately 3,000 species of fleas of 238 genera and 15 families. In Brazil, eight families, 20 genera and 60 species have already been reported. Fleas are important invasive agents and can act as parasites per se, harming their hosts, causing irritation, and inflammatory reactions (SOUSA, 1997), but they also act as vectors, transmitting pathogens to their hosts (POLLITZER; MEYER, 1965; BARLETT; JUDGE, 1997; LINARDI; GUIMARÃES, 2000; LINARDI et al. 2005; LINARDI, 2006; MINISTÉRIO DA SAÚDE, 2008).

There is a lack of scientific information on small rodents and marsupials living in the Pedra Branca State Park, as well as on the Siphonaptera species that use them as hosts, and the study of the relationship between small mammals and their ectoparasites may broaden our understanding about their ecological, evolutionary, and taxonomic aspects. Therefore, the purpose of the present study was to evaluate the flea fauna of rodents and marsupials in the Pedra Branca State Park.

\section{Materials and Methods}

Rodents and marsupials were captured using traps of different sizes during four consecutive days and nights in each one of the 24 months of investigation, from October 2005 to October 2007, totaling 13,200 traps/day. Trapping was conducted according to Mills et al. (1995) safety recommendations. The study site is located in the Pedra Branca State Park (PBSP) (22 56' 26" S and $43^{\circ} 26^{\prime} 28^{\prime \prime}$ W), an area of Atlantic Rainforest in the city of Rio de Janeiro, State of Rio de Janeiro. Six capture sites were delimited, beginning at into sections of altitude of $150 \mathrm{~m}$ up to $600 \mathrm{~m}$. Traps were distributed into five transects, one of them studied each month. Banana, ground beef with bacon and peanut butter were used as bait. After capture, mammals were anesthetized with ether, ear-marked, and fleas were collected with a small toothcomb. Fleas were preserved in $70 \%$ ethanol before being processed and mounted on glass slides for taxonomic identification. The nomenclature of Siphonaptera followed Johnson (1957) and the revision of the sub-family Rhopalopsyllinae was made according the nomenclature proposed by Linardi and Guimaráes (1993). Mammal species were identified using morphological characteristics (e.g. pelage color, body and tail size) based on descriptions available for Rodentia and Marsupialia (EMMONS; FEER, 1997; MUSSER; CARLETON, 2005; WEKSLER; PERCEQUILLO, 2006).

The captured mammals were released at the same capture site. Flea species are maintained in the Siphonaptera collection of the Vector Laboratory, Sérgio Arouca School of Public Health/ FIOCRUZ.

Data on diversity and richness of small mammal species were assessed by Shanon-Wiener index $(\mathrm{H})$ and Jackknife richness estimator (S) using the DIVES program (RODRIGUES, 2004) and data on parasitism were analyzed by prevalence of parasitism, Spearman's rank correlation coefficient (rs) to correlate the prevalence of fleas on hosts and altitude, coefficient of dominance, average intensity of parasitism and abundance rate. The statistical significance was set at a p-value of $<0.05$ (SERRA-FREIRE, 2002; AYRES et al. 2005).

Ethical considerations: captures of small mammals were authorized by the Brazilian Institute of Environment and Natural Renewable Resources (IBAMA) (license number 058/06-RJ, process number 02022.001749/2005-64), and State Institute of Forests of Rio de Janeiro (license number IEF/RJ/PR No. 015/05).

\section{Results}

The overall diversity of small mammals estimated during the study period was $\mathrm{H}=0.8$. Considering each section studied, the highest diversity and richness were $\mathrm{H}=0.79$ and $\mathrm{S}=13.5$ at $200 \mathrm{~m}$ and the lowest ones were $H=0.52$ and $S=6.0$ at 600 and $150 \mathrm{~m}$, respectively (Figure 1), totaling 160 mammals, of which 64 rodents (30 females and 34 males) and 96 marsupials ( 48 females and 48 males) from the following species: Cricetidae: Akodon cursor (Winge, 1887) (6/64), Oligoryzomys nigripes (Olfers, 1818) (4/64); Muridae: Rattus rattus (Linnaeus, 1758) (1/64), Rattus norvegicus (Berkenhout, 1769) (8/64); Sciuridae: Guerlinguetus ingrami (Thomas, 1901) (44/64); Erethizontidae: Sphigurus villosus (Cuvier, 1823) (1/64). The marsupials were: Didelphidae: Didelphis aurita

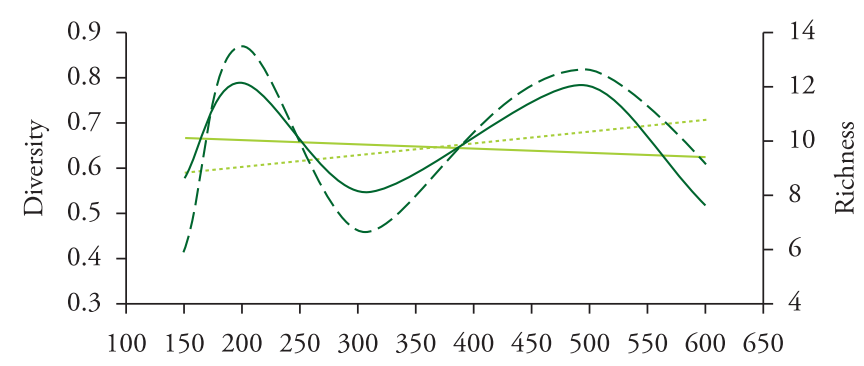

Altitude (m)

\begin{tabular}{|c|c|}
\hline — Diversity & Linear tendency of diversity \\
\hline Richness & Linear tendency of richness \\
\hline
\end{tabular}

Figure 1. Shanon-Wiener diversity and Jackknife richness of small mammal species per section, Pedra Branca State Park, Rio de Janeiro, Brazil, from October 2005 to October 2007. 
(Wied-Neuwied, 1826) (56/96), Marmosops incanus (Lund, 1840) (17/96), Micoureus paraguayanus (Tate, 1931) (18/96), Metachirus nudicaudatus (Geoffroy, 1803) (1/96), Monodelphis americana (Müller, 1776) (3/96) and Philander frenatus (Olfers, 1818) (1/96). The linear regression between richness and diversity indicated the influence of the first ecological data on the second one $\left(r^{2}=0.75\right.$, $\mathrm{p}<0.05$ ) (Figure 2). There were nine recaptures during the study period: four $M$. paraguayanus, two $D$. aurita, two $M$. incanus and one $G$. ingrami, and nine specimens of P.occidentalis were recovered. The frequency of captured mammals and their related prevalence of parasitism in each section are shown in Table 1.

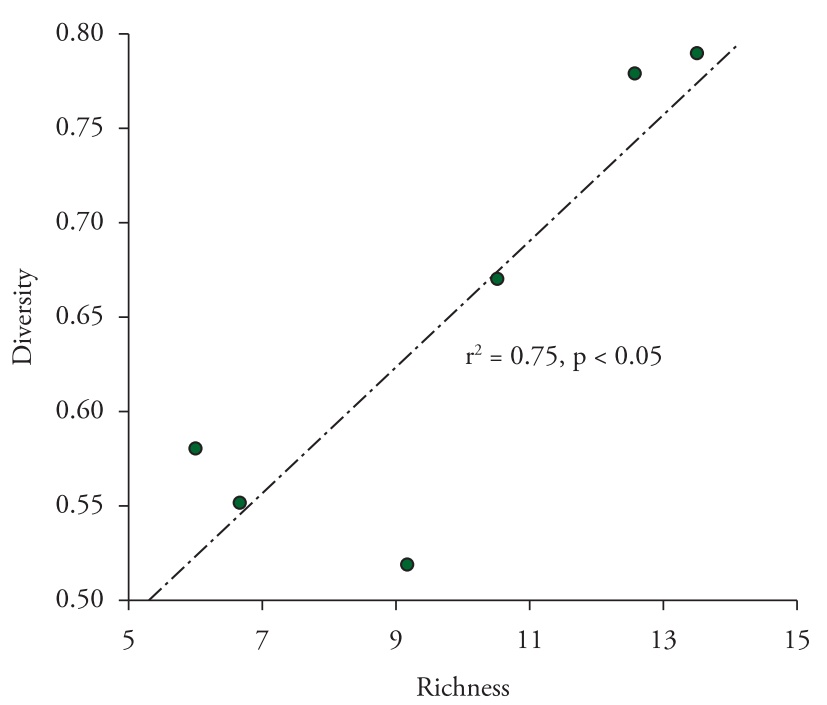

Figure 2. Goodness-of-fit linear regression between Shanon-Wiener diversity and Jackknife richness of small mammal species, Pedra Branca State Park, State of Rio de Janeiro, Brazil, from October 2005 to October 2007.
There were 162 flea specimens (78 females and 84 males, sex ratio $=0.92$ ) exploiting small mammals in PBSP, of which 37 $(22.8 \%)$ in only one rodent species, G. ingrami (19 females and 18 males, sex ratio $=1.05)$, and $125(77.2 \%)$ in marsupials, of which $D$. aurita $(50$ females and 61 males, sex ratio $=0.81$ ) was the most parasitized (68.6\%). They belonged to three families and six species, and Adoratopsylla (Tritopsylla) intermedia intermedia (Wagner, 1901) was the most abundant, 74.7\% (121/162) of total fleas collected, and was more commonly seen on D. aurita (89.2\%), followed by Polygenis (Polygenis) occidentalis occidentalis (Cunha, 1914) (19.8\%; 32/162), P. (P.) rimatus (Jordan, 1932) (19.8\%; 6/162), Adoratopsylla (Adoratopsylla) antiquorum antiquorum (Rothschild, 1903) (0.6\%; 1/162), P. (Neopolygenis) atopus (Jordan and Rothschild, 1922) $(0.6 \% ; 1 / 162)$, and Ctenocephalides felis felis (Bouché, 1835) (0.6\%; 1/162) (Table 2).

The overall prevalence of fleas was $25.6 \%$ ( 41 mammals parasitized out of 160 examined). Twenty-seven out of 96 marsupials examined $(28.1 \%)$, and among rodents, 14 squirrels of 64 examined (21.9\%) were parasitized. Neither the prevalence found among marsupials and rodents, nor the sex ratio of fleas on their hosts nor the positive correlation seen between prevalence and altitude were statistically significant $\left(\chi^{2}=0.8, \mathrm{p}>0.05 ; \chi^{2}=0.8, \mathrm{p}>0.05 ; \mathrm{rs}=0.26\right.$, $\mathrm{p}>0.05$ ). The average intensity of parasitism (AIP) was 3.95 fleas/ host $\left[\mathrm{AIP}_{\text {rodents }}=2.64\right.$ fleas $/$ rodent; $\mathrm{AIP}_{\text {marsupeials }}=4.63$ fleas $/$ marsupial $]$, and the rate of abundance was 0.59 fleas/rodent and 1.30 fleas/ marsupial.

The calculated dominance of the Ctenophthalmidae family was $75.3 \%$, of the Rhopalopsyllidae family was $24.1 \%$, and of the Pulicidae family was $0.6 \%$ (Table 2 ).

There were two types of multiple infestations, one triple on $D$. aurita and two double infestations on G. ingrami. The triple infestation was with $A$. intermedia intermedia and $P$. o. occidentalis and $C$. felis felis; the double infestations were with $P$. occidentalis occidentalis and $P$. rimatus and $P$. o. occidentalis and $P$. atopus.

Table 1. Species of small mammals stratified by frequency and prevalence of parasitism, captured monthly per section of the Pedra Branca State Park, Rio de Janeiro, Brazil, from October 2005 to October 2007

\begin{tabular}{|c|c|c|c|c|c|c|c|c|c|c|c|c|c|c|c|c|c|c|c|c|c|}
\hline \multirow[t]{3}{*}{ Mammals } & \multicolumn{21}{|c|}{ Collection sites (m) } \\
\hline & \multicolumn{3}{|c|}{150} & \multicolumn{3}{|c|}{200} & \multicolumn{3}{|c|}{300} & \multicolumn{3}{|c|}{400} & \multicolumn{3}{|c|}{500} & \multicolumn{3}{|c|}{600} & \multicolumn{3}{|c|}{ Total } \\
\hline & $\mathbf{N}$ & $\mathbf{P}$ & $\%$ & $\mathbf{N}$ & $\mathbf{P}$ & $\%$ & $\mathbf{N}$ & $\mathbf{P}$ & $\%$ & $\mathbf{N}$ & $\mathbf{P}$ & $\%$ & $\mathbf{N}$ & $\mathbf{P}$ & $\%$ & $\mathbf{N}$ & $\mathbf{P}$ & $\%$ & $\mathbf{N}$ & $\mathbf{P}$ & $\%$ \\
\hline Rodentia & 10 & 3 & 30.0 & 16 & - & - & 5 & 2 & 40 & 10 & 4 & 40.0 & 11 & - & - & 12 & 5 & 41.6 & 64 & 14 & 21.9 \\
\hline Akodon cursor & 1 & - & - & 1 & - & - & - & - & - & - & - & - & 4 & - & - & - & - & - & 6 & - & - \\
\hline Oligoryzomys nigripes & - & - & - & 2 & - & - & - & - & - & 1 & - & - & - & - & - & 1 & - & - & 4 & - & - \\
\hline Rattus norvegicus & 1 & - & - & 3 & - & - & - & - & - & 1 & - & - & 3 & - & - & - & - & - & 8 & - & - \\
\hline Sphigurus villosus & - & - & - & - & - & - & - & - & - & - & - & - & 1 & - & - & - & - & - & 1 & - & - \\
\hline Didelphimorphia & 28 & 7 & 25.0 & 20 & 8 & 40.0 & 7 & 1 & 14.3 & 24 & 7 & 29.2 & 5 & 1 & 20.0 & 12 & 3 & 25.0 & 96 & 27 & 28.1 \\
\hline Didelphis aurita & 20 & 7 & 35.0 & 11 & 6 & 54.5 & 3 & 1 & 33.3 & 10 & 4 & 40.0 & 4 & 1 & 25.0 & 8 & 2 & 25.0 & 56 & 21 & 37.5 \\
\hline Marmosops incanus & 4 & - & - & 5 & - & - & 3 & - & - & 5 & 2 & 40.0 & - & - & - & - & - & - & 17 & 2 & 11.7 \\
\hline Micoureus paraguayanus & 4 & - & - & 2 & - & - & - & - & - & 9 & 1 & 11.1 & 1 & - & - & 2 & - & - & 18 & 1 & 5.5 \\
\hline Total & 38 & 10 & 26.3 & 36 & 8 & 22.2 & 12 & 3 & 25.0 & 34 & 11 & 31.4 & 16 & 1 & 6.2 & 24 & 8 & 33.3 & 160 & 41 & 25.6 \\
\hline
\end{tabular}

$\mathrm{N}$ = number of captured hosts; $\mathrm{P}$ = number of hosts exploited by fleas; $\%$ = prevalence. 
Table 2. Number and frequencies of fleas collected on different small mammal species captured in the Pedra Branca State Park, Rio de Janeiro, Brazil, from October 2005 to October 2007

\begin{tabular}{|c|c|c|c|c|c|c|c|c|c|c|c|c|c|c|c|c|}
\hline \multirow{3}{*}{ Flea species } & \multicolumn{14}{|c|}{ Hosts } & & \\
\hline & \multicolumn{2}{|c|}{$\begin{array}{l}\text { Guerlinguetus } \\
\text { ingrami }\end{array}$} & \multicolumn{2}{|c|}{$\begin{array}{c}\text { Didelphis } \\
\text { Aurita }\end{array}$} & \multicolumn{2}{|c|}{$\begin{array}{l}\text { Marmosops } \\
\text { incanus }\end{array}$} & \multicolumn{2}{|c|}{$\begin{array}{c}\text { Micoureus } \\
\text { paraguayanus }\end{array}$} & \multicolumn{2}{|c|}{$\begin{array}{l}\text { Monodelphis } \\
\text { americana }\end{array}$} & \multicolumn{2}{|c|}{$\begin{array}{c}\text { Metachirus } \\
\text { nudicaudatus }\end{array}$} & \multicolumn{2}{|c|}{$\begin{array}{l}\text { Philander } \\
\text { frenatus }\end{array}$} & \multicolumn{2}{|c|}{ Total } \\
\hline & $\mathbf{N}$ & $\%$ & $\mathbf{N}$ & $\%$ & $\mathbf{N}$ & $\%$ & $\mathbf{N}$ & $\%$ & $\mathbf{N}$ & $\%$ & $\mathbf{N}$ & $\%$ & $\mathbf{N}$ & $\%$ & $\mathbf{N}$ & $\%$ \\
\hline Ctenophthalmidae & & & & & & & & & & & & & & & 122 & 75.3 \\
\hline $\begin{array}{l}\text { A. (A.) antiquorum } \\
\text { antiquorum }\end{array}$ & - & - & - & - & - & - & - & - & 1 & 100 & - & - & - & - & 1 & 0.6 \\
\hline $\begin{array}{l}\text { A. (T.) intermedia } \\
\text { intermedia }\end{array}$ & - & - & 108 & 97.3 & 2 & 100 & 2 & 100 & - & - & 4 & 100 & 5 & 100 & 121 & 74.7 \\
\hline Rhopalopsyllidae & & & & & & & & & & & & & & & 39 & 24.1 \\
\hline $\begin{array}{l}P .(P .) \text { occidentalis } \\
\text { occidentalis }\end{array}$ & 30 & 81.1 & 2 & 1.8 & - & - & - & - & - & - & - & - & - & - & 32 & 19.8 \\
\hline$P .(P$.$) rimatus$ & 6 & 16.2 & - & - & - & - & - & - & - & - & - & - & - & - & 6 & 3.7 \\
\hline P. (N.) atopus & 1 & 2.7 & - & - & - & - & - & - & - & - & - & - & - & - & 1 & 0.6 \\
\hline Pulicidae & & & & & & & & & & & & & & & 1 & 0.6 \\
\hline C. felis felis & - & - & 1 & 0.9 & - & - & - & - & - & - & - & - & - & - & 1 & 0.6 \\
\hline Total & 37 & 100 & 111 & 100 & 2 & 100 & 2 & 100 & 1 & 100 & 4 & 100 & 5 & 100 & 162 & 100 \\
\hline$(\%)$ & & & & .6 & & & & & & & & & & 2 & & \\
\hline
\end{tabular}

$\mathrm{N}=$ number of specimens; $\%$ = frequency of fleas; $(\%)=$ frequency of hosts.

\section{Discussion}

The fauna of small mammals found in the PBSP consisted of 12 species $(\mathrm{H}=0.8)$, and its diversity was influenced by richness $\left(r^{2}=0.75, p<0.05\right)$, although the linear tendency of these ecological parameters showed an inverse correlation, i.e., as diversity decreased richness increased (Figure 1 and 2). These findings were particularly influenced by high abundance of $D$. aurita and G.ingrami, species commonly found in all collection sites, which are considered opportunistic species together with the other four species, $A$. cursor, $O$. nigripes, $R$. rattus, and $R$. norvegicus (Table 1). High richness or abundance of these opportunistic or generalist species that can thrive in a wide variety of environmental conditions characterize the degree of fragmentation of the vegetation (RICKLEFES, 2003) caused by disorderly occupation of the park area as observed by Cáceres (2006). These sinantropic species, of which two are typically cosmopolitan, Roof and Norway rats, harbor various bioagents and their presence in the same wild territory promote the exchange and dissemination of infectious and parasitic agents (D'ANDREA et al., 2002; OLIVEIRA et al., 2001; MINISTÉRIO DA SAÚDE, 2002) into new hosts and environments, developing new relationships between hosts and parasites and favoring the occurrence of zoonoses and geographical epidemic spread (BARLETT; JUDGE, 1997). Nevertheless, the wild fauna found, S. villosus, $M$. incanus, $M$. paraguayanus, $M$. nudicaudatus, $M$. americana, and $P$. frenatus, despite their low abundance (Table 1), is important to the local environment. A governmental program of reforestation was established in this region 20 years ago (SMMA, 1999), and is now maintained and constantly supervised by the Environmental Department of the City of Rio de Janeiro. The study findings suggest it is a successful program and the local fauna of small mammals can be used as a parameter to indicate good environmental quality, as described by Zanzini (2001), and provide valuable information in landscape epidemiology studies (CORTES, 1993),

With regard to fleas, studies conducted in different Atlantic rainforest areas showed a rate of abundance that varied between 0.30 among rodents in Guaraqueçaba, in the State of Paraná (BICHO et al., 1999), and 3.06 among rodents and marsupials in Angra dos Reis, State of Rio de Janeiro (GUITTON et al., 1986). Botêlho et al. (2003) reported that Siphonaptera are parasites of rodents and marsupials in the Serra Negra Biological Reserve, State of Pernambuco, showing an average intensity of parasitism of 3.70 fleas/host, rate of abundance of 2.0 fleas/host, and the highest dominance of the family Rhopalopsyllidae, which could be explained by the fact that a higher number of rodents than marsupials were captured. The dominance of this family was also observed by Barros-Battesti and Arzua (1997), but the same was not confirmed in PBSP, where there was definitely a dominance of Ctenophthalmidae family. This difference in dominance could be due to the number of captured hosts of each order, approximately $3 / 5$ were marsupials, but the average intensities of parasitism on rodents and marsupials were similar in both studies. In addition, given that marsupials are their preferred hosts according to Linardi and Guimarães (2000), the prevalence of parasitism in both studies was similar $\left(\chi^{2}=0.8, p>0.05\right)$. The overall prevalence $(25.6 \%)$ found was lower than that reported in the Serra dos Órgãos National Park in the State of Rio de Janeiro where the lowest altitude studied was $800 \mathrm{~m}$ and the prevalence found was higher than $50 \%$, suggesting an effect of altitude and environment quality on the prevalence of flea fauna, which increases as altitude increases (CARVALHO et al., 2001a). The present study showed no relationship between the prevalence of small mammals exploited by fleas and the altitudes studied $(\mathrm{rs}=0.26, \mathrm{p}>0.05)$. Besides, the prevalence of sinantropic and wild mammals and the sex ratio were similar $\left(\chi^{2}=0.64, p>0.05\right.$; $\left.\chi^{2}=0.80, p>0.05\right)($ Table 1$)$, suggesting invasion of the wild 
environment by commensal mammals, but not by cosmopolitan fleas, considering that only one cat flea was found parasitizing a marsupial (Table 2). Fleas were found in all transect lines studied, which corroborates this finding.

Considering the preference of Polygenis for rodents as described by Machado-Alison (1962), Gomes (1969), and Linardi (1975), its occurrence on marsupials would be secondary infestations as also seen in the PBSP; however, it should be noted the fact that wild rodents were not parasitized, which could be explained by the low number of individuals captured in the traps.

According to Linardi and Guimarães (2000), P. (P.) occidentalis occidentalis has been reported in some states of the Northeast, Southeast and South regions in Brazil. The present study described their presence in a new geopolitical area in the state of Rio de Janeiro hitherto found only in the green coast, south of the State of Rio de Janeiro (CARVALHO et al., 2001b). There are other reports such as Philander frenatus and Micoureus paraguayanus, new hosts for Adoratopsylla (Tritopsylla) intermedia intermedia.

Linardi et al. (2000) reported that $C$. felis felis occurs quite frequently in Didelphis spp, both in Brazil and North America. However, in the PBSP, only one animal of the species $D$. aurita was infested. This flea species has as primary hosts domestic dogs and cats, where the adult species remains on the host body, leaving their hosts only to hatch. It could be inferred that, in the PBSP, marsupials, dogs and cats have not been in close contact yet.

The abundance and prevalence of $A$. antiquorum were $0.6 \%$. This specie was captured only on $M$. Americana as described by Morais et al. (2003) in a study developed in the Atlantic forest. The abundance found is lower than that reported by Gomes (1969) also in the Atlantic rainforest and Guimarães (1972) in Northeastern Brazil.

Fleas are a reservoir of Rickettsia typhi and R. felis, which are pathogens of murine typhus and these rickettsia are associated with the most prevalent rickettsial disease in Brazil, the Brazilian spotted fever group that is endemic in the states of Espírito Santo, Minas Gerais, and São Paulo (CARDOSO et al. 2006; OLIVEIRA et al. 2008), According to Azad et al. (1992), R. felis is maintained in cat flea by transovarial transmission, a characteristics that is of extremely importance to identify foci of this emerging disease. Recently Horta et al. (2007) reported $P$. atopus infected by $R$. felis, suggesting that this wild flea is a potential vector and reservoir. Cat fleas and $P$. atopus have dogs, rodents, opossum and humans as potential hosts (LINARDI; GUIMARÁES, 2000; LEMOS et al., 2001; CARVALHO et al., 2001a) and are endemic in the PBSP (Table 2). The disorderly urbanization and the use of the PBSP physical area for grazing threaten the park's integrity (COSTA et al., 2001). The unplanned occupation may be facilitating the development of a new focus of infectious diseases with the involvement of these arthropod vectors. More studies are needed in this area space to further explore the risks on invasion into these areas.

\section{References}

AYRES, M. et al. BioEstat 4.0: aplicação estatística nas áreas das ciências biológica e médica. Brasília, DF: Sociedade Civil Mamirauá, 2005.

AZAD, A. F. et al. Genetic characterization and transovarial transmission of a typhus-like rickettsia found in cat fleas. Proceedings of the National Academy of Sciences, v. 89, p. 43-46, 1992.
BARLETT, P. C.; JUDGE, L. J. The role of epidemiology in public health. Office International des Epizooties. Scientific and Technical Review, v. 16, n. 2, p. 331-336, 1997.

BARROS-BATTESTI, D. M.; ARZUA, M. Geographical distribution by biomes of some Marsupial Siphonaptera from the state of Paraná, Brazil. Memórias do Instituto Oswaldo Cruz, v. 92, n. 4, p. 485-486, 1997.

BICHO, C. L. et al. Siphonaptera de roedores silvestres em Guaraqueçaba, Paraná, Brasil. Entomologia y Vectores, v. 6, n. 1, p. 53-62, 1999.

BOTÊLHO, M. C. N. et al. Sifonápteros parasitos de marsupiais e pequenos roedores silvestres da reserva Biológica de Serra Negra, Pernambuco, Brasil - Registro de novos hospedeiros. Revista da Universidade Rural, Série Ciências da Vida, v. 22, n. 2, p. 71-74, 2003.

BRASIL, D. P. et al. Pesquisa da infecção natural por Yersinia pestis, em pulicídeos provenientes de focos pestosos do nordeste do Brasil. Revista da Sociedade Brasileira de Medicina Tropical, v. 22, p. 177-181, 1989.

BROOKS, T.; BALMFORD, A. Atlantic Forest extinctions. Nature, v. 380, p. $115,1996$.

CÁCERES, N. C.; MONTEIRO-FILHO, E. L. A. Os marsupiais do Brasil: biologia, ecologia e evolução. Campo Grande, MS: Universidade Federal do Mato Grosso do Sul, 2006. 364 p.

CARVALHO, R. W. et al. Sifonápteros de Pequenos Roedores da Costa Verde, Região Sul do Estado do Rio de Janeiro, Brasil. Entomologia y Vectores, v. 8, n. 3, p. 385-390, 2001 b.

CARVALHO, R. W. et al. Small rodents fleas from the bubonic plague focus located in the Serra dos Órgãos Mountain Range, State of Rio de Janeiro, Brazil. Memórias do Instituto Oswaldo Cruz, v. 96, n. 5 , p. 603-609, 2001a.

CORTES, J. A. Epidemiologia. São Paulo: Varela, 1993. 195 p.

COSTA, N. M. et al. Potencial de Erodibilidade das Bacias Hidrográficas do maciço da Pedra Branca - RJ. In: MARAFON, G. J.; RIBEIRO, M. F. (Org.). Estudos de Geografia Fluminense. Rio de Janeiro: Eduerj, 2001. 209 p.

D'ANDREA, P. S. et al. Experimental evidence and ecological perspectives for the adaptation of Schistosoma mansoni (Digenea: Schistosomatidae) to a wild host, the water-rat, Nectomys squamipes Brants, 1827 (Rodentia: Sigmodontinae). Memórias do Instituto Oswaldo Cruz, v. 97, n. s1, p. 11-14, 2002.

DEAN, W. A ferro e fogo: a história e a devastação da Mata Atlântica brasileira. São Paulo: Companhia das Letras, 1995. 484 p.

EMMONS, L. H.; FEER, F. Neotropical Rainforest Mammals: a field guide. Chicago: The University of Chicago Press, 1997. 307 p.

FONSECA, G. A. B. The vanishing Brazilian Atlantic Florest. Biological Conservation, v. 34, n. 1, p. 17-34, 1985.

GOMES, A. C. Pulgas colhidas em residências e sobre pequenos animais de algumas áreas do Brasil. Revista Brasileira de Malariologia e Doenças Tropicais, v. 21, n. 4, p. 775-779, 1969.

GUIMARÃES, L. R. Contribuição à epidemiologia da peste endêmica no nordeste do Brasil e estado da Bahia. Estudo das pulgas encontradas nessa região. Revista de Malariologia e Doenças tropicais, v. 24, n. 1-4, p. $95-163,1972$ 
GUITTON, N.; ARAÚJO-FILHO, N. A.; SHERLOCK, I. A. Ectoparasitos de roedores e marsupiais no ambiente silvestre de Ilha Grande, Estado do Rio de Janeiro, Brasil. Memórias do Instituto Oswaldo Cruz, v. 81, n. 2, p. 233-234, 1986.

HORTA, M. C. et al. Rickettsia infection in five areas of the state of São Paulo, Brazil. Memórias do Instituto Oswaldo Cruz, v. 102, n. 7, p. 793-801, 2007.

JOHNSON, P. T. A Classification of the Siphonaptera of South America with descriptions of new species. Washington, D.C.: Entomological Society of Washington, 1957. 298 p.

LEMOS, E. R. et al. Spotted fever in Brazil: a soroepidemiological study and description of clinical cases in an endemic area in the State of São Paulo. American Jounal of Tropical Medicine and Hygiene, v. 65, n. 4, p. 329-334, 2001

LINARDI, P. M. et al. Polygenis (Polygenis) platensis (Jordan \& Rothschild) (Siphonaptera: Rhopalopsyllidae, Rhopalopsyllinae), a new record in Brazil. Neotropica Entomology, v. 34, n. 5, p. 837-841, 2005.

LINARDI, P. M. Novos rumos para a sistemática de pulgas. Ciência e Cultura, v. 27, n. 8, p. 720-722, 1975.

LINARDI, P. M. Os ectoparasitos de marsupiais brasileiros. In: CÁCERES, N. C.; MONTEIRO-FILHO, E. L. A. (Org.). Os marsupiais do Brasil: biologia, ecologia e evolução. Campo Grande: UFMS, 2006. v. 3, p. 37-52.

LINARDI, P. M.; GUIMARÃES, L. R. Sifonápteros do Brasil, São Paulo: Museu de Zoologia da USP, 2000. 291 p.

LINARDI, P. M.; GUIMARÃES, L. R. Systematic Review of Genera and Subgenera of Rhopalopsyllinae ( Siphonaptera: Rhopalopsyllidae) by Phenetic and Cladistic Methods. Journal of Medical Entomology, v. 30, n. 1, p. 161-170, 1993.

MACHADO-ALLISON, C. E. Consideraciones sobre la distribucion y huespedes de la tribu Rhopalopsyllini. Acta Biologica Venezuelana, v. 3, p. 173-193, 1962.

MILLS, J. N. et al. Methods for trapping and sampling small mammals for virologic testing. Atlanta: Center for Disease Control and Prevention, $1995.198 \mathrm{p}$.

MINISTÉRIO DA SAÚDE. Controle de roedores. Brasília, DF: Fundação Nacional de Saúde, 2002.

MINISTÉRIO DA SAÚDE. Manual de Controle da Peste. Brasília, DF: Secretaria de Vigilância em Saúde, 2008. 92 p.

MORAIS, L. B.; BOSSI, D. E. P.; LINHARES, A. X. Siphonaptera parasites of wild rodents and marsupials trapped in three mountain ranges of the Atlantic Forest in Southeastern Brazil. Memórias do Instituto Oswaldo Cruz, v. 98, n. 8, p. 1071-1076, 2003.

MUSSER, G. G.; CARLETON, M. D. Superfamily Muroidea. In: WILSON, D. E.; REEDER, D. M. (Eds.). Mammal Species of the
World a Taxonomic and Geographic Reference. Baltimore: Johns Hopkins University Press, 2005. p. 894-1531.

MYERS, N. et al. Biodiversity hot spots for conservation priorites. Nature, v. 403, p. 853-858, 2000.

OLIVEIRA, K. A. et al. Molecular identification of Rickettsia felis in ticks and fleas from an endemic area for Brazilian Spotted Fever. Memórias do Instituto Oswaldo Cruz, v. 103, n. 2, p. 191-194, 2008.

OLIVERA, H. H. et al. Anopluros de roedores dos focos pestígenos da Serra dos Órgãos, municípios de Nova Friburgo, Teresópolis e Sumidouro, Estado do Rio de Janeiro, Brasil. Entomologia y Vectores, v. 8, p. 229-243, 2001.

POLLITZER, R; MEYER, K. F. Plague in the Americas. Washington: WHO, 1965. p. 156. (Scientific Publication, v. 115)

RICKLEFES, R. E. A economia na natureza. Rio de Janeiro: Guanabara Koogan, 2003. 470 p.

RIO DE JANEIRO. Secretaria Municipal de Meio Ambiente - SMMA. Mutiráo de Reflorestamento: as florestas preservando a cidade. Rio de Janeiro, 1999. 18 p.

ROCHA, C. F. D. et al. Fauna de anfíbios, répteis e mamíferos do Estado do Rio de Janeiro, sudeste do Brasil. Publicaçóes Avulsas do Museu Nacional, v. 104, p. 1-24, 2004.

RODRIGUES, W. C. Dives - Diversidade de espécies. [S.1]: Lizaro soft; Entomologistas do Brasil, 2004.

SERRA-FrEIRE, N. M. Planejamento e Análise de Pesquisas Parasitológicas. Niterói: Editora UFF, 2002. 195 p.

SIMON, R. Experiências sobre a capacidade transmissora da Rhopalopsyllous bohlsi jordani e inquérito pulicidiano em focos silentes. Brasília, DF: Ministério da Educação e Saúde, 1954. 40 p. (Monografias do Serviço Nacional de Peste).

SOUSA, C. A. Fleas, flea allergy, and flea control, a review. Dermatology Online Journal, v. 3, n. 2, p. 7, 1997.

WEBB, L. et al. Detection of Murine Typhus in fleas by using Polymerase Chain Reaction. Journal of Clinical Microbiology, v. 28, n. 3, p. 530-534, 1990.

WEKSLER, M.; PERCEQUILLO, A.; VOSS, R. Ten new genera of Oryzomyine rodents (Cricetidae: Sigmodontinae). American Museum Novitates, v. 3537, p. 1-29, 2006.

WORLD HEALTH ORGANIZATION - WHO. Plague manual, Epidemiology, Distribution, Surveillance and Control. Communicable disease Surveillance and Response. Geneve, 1999. 155 p.

ZANZINI, A. C. S. Princípios de ecologia e manejo da paisagem para a conservaçáo da fauna silvestre. A fauna Silvestre: conceituaçáo e relaçóes de importância na paisagem. Lavras-MG: Ed. Universidade Federal de Lavras, 2001. 117 p. 